\title{
Expanding enterprise engineering paradigm ${ }^{1}$
}

\author{
Evgeny Z. Zinder \\ Chairman of the Board, NCO "Foundation for System Engineering, \\ Standardization and Project Management Support" (FOSTAS Foundation) \\ Address: mailbox 563, Moscow, 107061, Russian Federation \\ E-mail: ezinder@fostas.ru
}

\begin{abstract}
The nature of changes in the enterprise engineering paradigm and, in the first place, in the concepts of this complex discipline, is important for the selection of enterprise engineering (EE) areas development and forms of accumulation of knowledge in this area and their transfer to professionals, as well as for the stability and flexibility of application of EE in practice. Analysis of these changes is particularly important, due to the high turbulence of EE methods and technologies in the modern segment of technology development, productive and other relations, as well as due to the possibility of interpretation of private schemes and methods of EE as a new paradigm.
\end{abstract}

To give a meaningful estimate of changes in the EE paradigm, there have been defined basic and additional EE concepts that at the end of the 20th century formed the classical EE paradigm. The results of comparative analysis of classical EE paradigm concepts and the tasks which are common to various enterprises until 2030 have been set forth. These results demonstrated that the classical EE paradigm retains its performance ability in this perspective. The paper points out the open character of the set of EE paradigm concepts and methods, whereby its composition naturally comprises the concepts formulated already in the 21st century, as well as alternative concepts. Meanwhile, the total "picture of the EE world" does not change to something incompatible with the former one, but at the same time it does not remain unchanged: we see a permanent expansion of the EE paradigm due to new methods of implementing the concepts, as well as new concepts applied in parallel and in combination with the classical ones.

The conducted analysis has allowed us to pass on to the definition of substantively new concepts and emerging ones, to propose directions for further research, as well as to define the conditions under which the formation and application of a truly new EE paradigm can be justified.

Key words: enterprise, enterprise engineering, concept of engineering, information technology, digital transformation, classical paradigm, paradigm shift, expanding paradigm.

Citation: Zinder E.Z. (2016) Expanding enterprise engineering paradigm. Business Informatics, no. 4 (38), pp. 7-18. DOI: 10.17323/1998-0663.2016.4.7.18.

\section{Introduction}

$\mathrm{D}$ uring the last twenty-five years, enterprise engineering (EE) has been defined as a complex discipline that is used for creating and changing a wide variety of enterprises. In consequence of goaloriented international efforts, at the end of the 20th century there was created a body of concepts, methodolo- gies and standards which together form the classical EE paradigm. This body was aimed at supporting the activities of enterprises in the 21st century, and its openness, backed by the standards [1,2], made it possible to build up and modernize its methods.

The current period is characterized not only by the acceleration of development of technologies (not only

1 The present research paper has been executed within the framework of project RFBR 16-07-01062:

"Development of methods and resources of enterprise engineering based on the smart technologies". 
information technologies, but also robotics, biotechnology, etc.), but also by radical changes in the education, demography, sociology, and economics in general, and this fact changes the environment in which enterprises are created and operate. Starting from the very beginning of the 21st century, changes in individual disciplines related to the EE began to be perceived as significant paradigm shifts. Furthermore, an impression has formed that the effect of a permanent paradigm shift [3] appeared. Nowadays, publications about new paradigms or their shifts occur almost daily. Some presentation about the turbulence in EE concepts and methods is provided in research papers [4-10], although the full picture is wider and more varied.

Under these conditions, the following questions should be answered:

$\checkmark$ Does the classical EE paradigm remain operable today and in the near future, and to what extent?

$\downarrow$ Do changes in enterprises and their external environment really require a new EE paradigm (or, equivalently, its paradigm shift) that is a radically changed picture of the EE world?

$\downarrow$ What EE concepts and methods should be rightfully and reasonably considered as classical or relatively new ones, but requiring further research and development (R\&D)?

$\checkmark$ What substantially new concepts in various areas of EE is it appropriate to consider as objects and directions for further research?

$\downarrow$ What are the conditions that require the recognition of a truly new EE paradigm, and what in this recognition can have both objective and subjective grounds?

The answers to these questions and their discussion are rather important for determining reasonable methods of EE development, as well as for the possibility itself of the systematic knowledge accumulation in this field and for selection of forms of passing them to experts, as well as for the flexible and sustainable implementation of EE methods in practice. The paper suggests answers to the first two questions and, partially, to the third of these questions, based on the classical EE paradigm concept and its expansions and development prospects.

Section 1 presents the approaches and methods used in the research. Section 2 states the results of analysis of the classical EE paradigm basic concepts, as well as the concepts that have greatly supplemented the basic ones and together with them formed the classic enterprise engineering. Section 3 presents the most common assessments of the main current objectives of enterprise engineering, often referred to as the digital transforma- tion. The classical EE paradigm concepts are compared with the mentioned objectives, and on this basis, assessments of operability of the existing EE paradigm and of the grounds for its replacement are being formed. Section 4 provides a diagram demonstrating the expanding EE paradigm, covering the application of relatively new concepts and discussion of radically new ones. Finally, the general program for further research required to obtain answers to the remaining questions is outlined.

\section{Methodology of the research \\ 1.1. The bases of the analysis methodology}

The methodological basis of the analysis is a comprehensive approach to EE analysis, the basic provisions of the non-classical and post-non-classical epistemology, as well as the historical approach applied to the values that EE provides to enterprises and to the people related to them. The principles of non-classical and post-non-classical epistemology serve for the expansion of the analysis basis in terms of choice of criteria for the selection of knowledge categories for the EE in general and individual EE concepts, particularly in relation to knowledge management engineering at enterprises. The historical approach is applied to analyze EE concepts and methods not in abstract "time and space", but within a particular historical period possessing certain characteristics of the enterprise environment, including characteristics of both the productive forces and the productive and social relations, as well as their dynamics, namely, within the horizon from the early 90 s of the 20th century to 2030 . The historical approach to $E E$ is applied in its searching variant, aimed at analysis of the EE concepts with consideration of future conditions of the enterprise within the planning horizon under review.

\subsection{The governing points of view on $\mathbf{E E}$ and related concepts}

Points of view of customers and users of the engineering results, as well as independent consultants considering the enterprises transformation from the standpoint not of individual technologies, but of the economy and society in general were chosen as governing ones for the evaluation of EE concepts. Particularly, the most important ones considered were both the criticism of unjustified imposition of the enterprise transformation methods from the standpoints of practical marketing at the beginning of the 21st century [10] and evaluation by the marketing management practitioners of new opportunities one and a half decades later [11]. Current forecasts and recommendations for enterprises - leaders of the 
so-called "digital transformation" were also taken into consideration.

A broad interpretation of conception "paradigm" [9] was used which makes it possible to integrate the search for EE theoretical justifications with a leading practical development of the real EE, which, in fact, fuels the search for these justifications. The EE paradigm is considered at the level of its most general and fundamental premises considered as the EE concept. The emergence of new methods applied for the implementation of some or other concept, and, especially, of new tools and technologies, is not regarded as a paradigm shift.

The characteristics "digital" and "analog" are interpreted in accordance with the UN and the World Bank reports used in the paper, and these characteristics are not associated with a form of data storage and transmission.

\section{The classical paradigm of enterprise engineering and its first expansions}

\subsection{Creation of the classical paradigm}

The classical EE paradigm concepts are rather completely presented in certain methodologies and standards. Analysis of the emergence and development of the classical EE in the light of its architectural part is carried out by the author in [12]. For this reason, only distinctive features of the classical EE used for evaluating paradigm operability are described further in the paper.

It is significant that more than twenty years ago some methodologists expressed the opinion that the EE paradigm as a new professional discipline is determined in general, both the engineering and technocratic ones [13]. However, the practical EE has been developed with the help of a large range of specialists, and has integrated a wider range of the enterprise aspects; this has made it possible to include various and often opposed concepts in practical use in EE. At ICEMIT'97 conference, governing for the EE, the results of goal-oriented research and a combination of the approaches of European and American specialists were presented [14]. However, although the name "EE" was introduced earlier at ICEMIT'92, the content of this discipline still required definition. Significant projects of a conceptual nature contributed to this, and the paper [15] indicated focusing of the proposed concepts on ensuring of successful enterprises operation in the 21st century.

A consensus regarding the EE concepts was generally reached in 2000 which was reported by Kurt Kosanke, one of the EE ideologists, in a research paper [16]. The standards $[1,2]$ were approved that established the term "enterprise engineering" and the basic concepts of en- terprises integration and modeling, as well as a broad definition of the term "enterprise" and principles of EE implementation, including those based on the architectural approach. These and subsequent EE standards have been harmonized with the concepts of a number of methodologies still having independent significance.

\subsection{Basic concepts of the classical EE paradigm}

In this paper the author attributes the concepts that are set forth in descriptions of the projects and standards, which in fact have formed the basis of EE content, as basic. As such, in the first place this research paper considers projects GERAM [17], CIMOSA [18], GRAI-GIM [19] and Next-Generation Manufacturing (NGM) [15], as well as standards [1,2]. The basic concepts can be divided into the three provisional fields: concepts of $\mathrm{EE}$ arrangement as a whole, concepts of individual components or aspects of an enterprise, and concepts of approaches to the enterprise integration. This paper states the most significant and indicative concepts, and their sets in each field are defined as open ones.

The basic concepts of the classical EE as a whole are as follows:

- Interpretation of the EE object as an enterprise comprising the goal-oriented nature of its establishing, modifying and functioning, not limiting the legal, economic or other aspects of its organization, size and life history, and providing for virtual and extended enterprises;

$\downarrow$ Enterprise engineering as a course through the life cycles that are forming the enterprise life history, as a continuous process of forming and changing descriptions and models of the enterprise, their adaptation and implementation by means of creating operational components and monitoring their functioning;

$\downarrow$ Subject and discipline "Enterprise Architecture" as a part of EE;

$\downarrow$ A multilevel system of detailed and concretized descriptions, illustrative representations and other enterprise models of varying formalization degree (including glossaries, ontological theories, typical (reference) and specific models, architectural modules), as well as ready-made blocks;

- Agile production and flexible structure of an enterprise, control over the balance between integration and decentralization of the enterprise's development.

The basic concepts for the enterprise components are as follows: 
$\diamond$ People as the enterprise subjects (their roles, competences, and special properties, interaction with each other and with machines), as well as the enterprise culture - both general and production;

$\diamond$ Business model of the enterprise in general and the set of its constituent models for various aspects of the enterprise, including the financial and economic model of the enterprise as part of the business model;

$\diamond$ Value chains and performance models of the enterprise and its engineering, as well as their integration;

$\diamond$ Products and models of the products in its life cycle, as well as other assets (resources) of the enterprise and their models;

$\diamond \mathrm{A}$ broad concept of enterprise processes, including behavior acts, as well as taxonomies of processes;

$\diamond$ Machinery and technological systems, their models and specimens;

$\diamond$ Information and knowledge of the enterprise;

$\diamond$ Centers of decision-making in the enterprise, architecture of the set of these centers and their relationships;

Re-usable modules (architectural units, services, standard and typical systems, information resources, etc.), and flexible enterprise architecture;

$\diamond$ External environment of the enterprise and its components; interaction with partners in the extended enterprise.

The basic concepts of approaches towards the enterprise integration are as follows:

- Architectural analysis, design, and control as a high-level management of enterprise integration and development;

- Standardization and typification of architectures and individual models, modules typification;

$\downarrow$ Various (heterogeneous) representations of partial architectures and processes of modeling of the enterprise and its architecture targeted at EE various subjects;

Adaptation of the reference methodologies, architectures, and the EE entire framework to the conditions of a particular industry and enterprise;

$\downarrow$ Construction and continuous actualization of the enterprise ontology as an integrated formalized description of the enterprise components, including its management, as well as management of their properties and relationships;

$\downarrow$ Multi-level organizational, informational and other interoperability of the enterprise components and the enterprise with its partners;

$\downarrow$ Integration of various functional parts, organizational units, and enterprise processes; $\downarrow$ Integration of machines, computer systems, and people;

$\downarrow$ Integration of virtual and extended enterprises (employees and partners);

\ Modeling languages, repository of artifacts of architecture and of the entire process of enterprise engineering;

Application of various enterprise life cycle models for different engineering methods (business process reengineering, continuous process improvement, etc.);

$\downarrow$ Integration of work processes based on workflow models.

\subsection{Concepts of the 20th century supplementing the EE basic concepts}

Simultaneously with the formation of the basic concepts, concepts related to further development of capabilities of enterprises have also been proposed. These concepts are reflected in the aforementioned documents of the classical EE only partially, but by 2001 they had already been applied in practice. This fact allows us to consider that the classical EE paradigm has been formed as a combination of the basic concepts described above and the additional concepts discussed below.

\section{Concepts for cyber-corporation engineering}

$\mathrm{J}$. Martin introduced the idea of a cyber-corporation in the paper [20], and developed it in 1996 in his book [21], in which he proposed concepts that seemed to be revolutionary for the major part of enterprises. The basis consisted in requirements for enterprises to respond quickly to changes, to implement a "corporate nervous system" distributed to partners and customers, to transform enterprises on the basis of net-centric architectures and continuous evolution of corporations as "electronic organisms".

Amongst others, these concepts include in particular the following [21]:

$\diamond$ To expose to reengineering not business processes, but value streams, thereby obtaining clear and measurable benefits;

$\diamond$ To plan the strategic advantages basing on the most important value streams;

$\diamond$ To realize flexibility and agility of creation and cancellation of network organizational ties to respond quickly to business opportunities;

$\diamond$ To form ecosystems of the economy of cyber-corporations as multi-industry combinations of corporations with dynamic relationship management;

$\diamond$ To use software agents and smart "digital" documents having "embedded intelligence"; 
To manage the choreography of complex interactions with partners in the network;

$\diamond$ To take "paradoxical" (sudden, spontaneous, illogical from the point of view of observers) behavior into consideration;

$\diamond$ To design a cyber-corporation for very quick evolution;

$\diamond$ To design parts of a cyber-corporation as "learning laboratories" aimed at continuous experiment.

A section of the book [21] is devoted to concepts of involving people and management. Among other things, it proposes the following:

$\downarrow$ To create an attractive and motivating work environment as an "exciting" place for maximum creative activity;

$\downarrow$ To carry out continuous quick training of people and the whole cyber-corporation; to exclude any outdated thinking;

\ To look for ways of "smooth transformation" as opposed to traumatic one.

In fact, these concepts had not been absolutely revolutionary ones by 1996, because in many respects they were similar to the well-known BPR concepts of the 90s [22]. However, J. Martin proposed a new approach based not so much on processes but on values, taking into consideration the high volatility of the environment. This approach required from enterprises the quickest possible response both to the emerging opportunities and to the requirements for development, forcing them to rely on information technologies to the most extent with the goal of achieving such an effect that in ten and more years became known as "digital transformation".

\section{Concepts for "New System Design" (N.S.D.)}

In those same years, the author of this article in his papers [23, 24], along with an analysis of the existing approaches, has proposed a system of concepts for developing automated systems that implement the operating part of comprehensively computerized enterprises. The sum of the concepts was called the "New System Design" (N.S.D.); it has received a significant number of citations and was used in universities and research independently from the author. Partially, the N.S.D. concepts turned out to be intercrossing with the proposals of J. Martin [21], as well as with certain developments published later. Therefore, we will consider only those aspects that can supplement these proposals:

$\diamond$ “Information Systems" are not technologies, but a directly acting part of a business (enterprise); it is interpreted as the need to always create and develop IT systems within the frame of business-engineering projects;

$\diamond$ An open "EE shop", extendable by means of alternative methods and tools in contrast to a "unitary" set of tools and predetermined methods;

Complete informational equipment of each employee, regardless of his position in the organizational structure.

\section{Concepts for electronic business enterprises}

In 1998, P. Timmers analyzed business models of electronic business enterprises in the paper [25], the number of citations of which has been increasing over the years. As a consequence, he, in fact, highlighted the concept of an "enterprise as a platform" (EaaP), as well as implicitly suggested a taxonomy of transaction and innovative platforms (although such names were not used in his own work). Among those discussed, there are platforms suitable for the creation of ecosystems, including not only companies, but also end customers. P. Timmers stated that these business models are feasible only because of the openness and connectivity provided by the Internet. The paper [25] also considers the following:

- The concept of innovative enterprise business models including added value to the value chain due to new information management methods and new functionality;

- The concepts of an enterprise with models of a "collaboration platform" and "virtual community", which afterwards came to be considered as the basis of e-participation concepts in e-governments and found use in various forms of modern social networking on the web.

\section{About other classical concepts of the EE}

Within the limits of this publication, it is impossible to consider many important concepts of the classical EE paradigm, however, they are reflected in the publications mentioned above. As an example, we will mention two important concepts defined in the NGM project:

$\diamond$ In the aspect of skills and activities of companies in the 21st century: "partnerships will be formed based on trust rather than through detailed contract in order to solve complex problems quickly" [15, p. 8];

$\diamond$ In the aspect of supplementary methods and technologies: "Tools to mitigate the effects of physical and cultural complexity and to enable effective distributed, global operations across cultures" [15, p. 9]. 


\section{General stimuli and objectives of changing enterprises in the 21 st century}

To evaluate the operability of the classical EE paradigm, it is reasonable to highlight the objectives and methods of enterprises development which are called "digital transformation" (DT), that seem to be relevant in the selected horizon, and are the most common for enterprises in different countries. Such objectives and methods of development are determined in this paper basing on the researches of the World Bank [26] and the UN [27, 28].

\subsection{Report of the World Bank: "Digital dividends"}

The report [26] is coordinated with the plan for sustainable development [29] adopted by the UN for the period up to 2030. The report [26] considers digital technologies in the first place as the Internet and mobile communications, as well as related information technologies - business intelligence (including big data technologies), work automation, and remote teamwork platforms. For all the industry sectors, enterprise scopes and kinds of activities, consideration is given to three main "mechanisms" for DT [26] or, in effect, EE models: inclusion in the information space, automation and coordination to improve efficiency, and savings through scale and platform for creating innovations.

The report [26] demonstrates that within the terms of perspective under consideration EE will be applied to the fullest extent in the DT area, which we will call the first one - for the development and transformation of classical enterprises and processes of production of relatively traditional products and services. The main objectives consist of covering a larger number of market participants, acceleration of the enterprises response and improvement of the efficiency of production processes planning and implementation. To achieve these goals, such models as "Inclusion" and "Automation and coordination" (or EE efficiency model in Figure 1) are applied in the first place. They are located at the bottom of Figure 1 which presents the scheme of EE models for DT including and extending ideas of [26]. It should be also noted that these models are completely covered by the classical EE paradigm concepts and are largely tried and tested in practice.

For a clearer comparison of the classical EE concepts with the second relevant DT area discussed below let us take into consideration that the model "Savings through scale and platform" should be divided into two ones: "Transaction platform" and "Innovation platform", which are at the top of Figure 1. This division takes place in both the recent taxonomy of platforms [30] and in the classical taxonomy of Internet business models [25]. On conceptual level combination of relations between these four models (mechanisms for DT) forms the integration grid and serves as the fifth model for DT: "EE top level integration model". Due to that the scheme is named "Five-model EE scheme for DT" in this paper.
For what: reduction in transaction costs, increasing number of sellers and customers (cost saving due to the scale of work on the transactional side and eliminating of middlemen)
For what: increased competition ability, new quality (novelty products creation, rapid and constant update of products, co-creation, customer's involvement and participation)

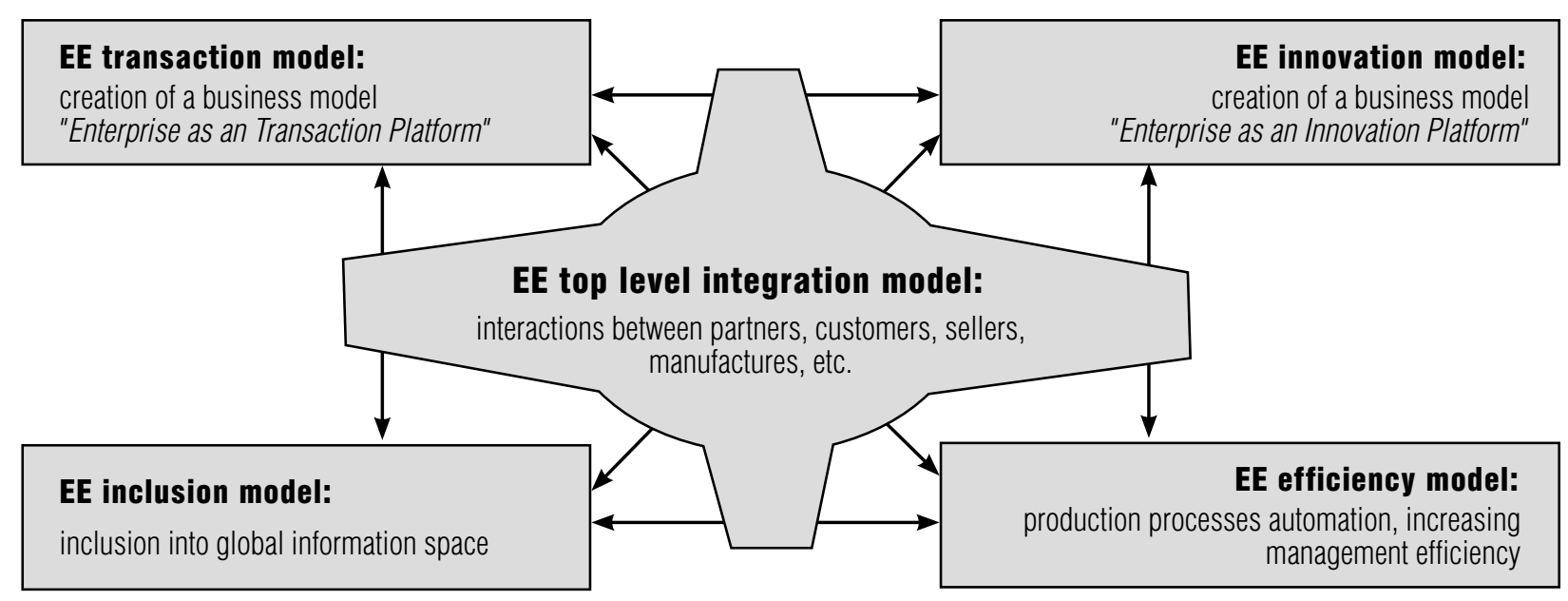

For what: coverage of a much larger space of distribution, customer settings, improving workflow

For what: a significant or even drastic increase in planning and production efficiency, quality of services and products

Fig. 1. The five-model scheme of $\mathrm{EE}$ for digital transformation of enterprises 
The second DT area covers those enterprises (divisions of enterprises), the production process of which is aimed at obtaining new or relatively innovative types of services in the form of information and communication results, primarily with the use of transaction and innovative platforms. The examples of application of the transaction platforms are electronic trading platforms or transfer of logistics and occasional services to the ICT sphere ("Uberization" - according to the operating model of Uber). The examples of application of the innovative platforms are the collective design of a new product at the site of a joint remote work or use of crowdsourcing to support decision-making about an urban area improvement. It can be noted that despite the relative novelty of such platforms, the classical EE basic concepts and models work in this engineering as well.

The report [26] brings ensuring of connectivity of organizations and people through the Internet and mobile communications to the leading position regarding the digital transformation effect. Undoubtedly, EE science intensive methods and intelligent technologies are also important. In classical EE, they are primarily used in the scope of the "Automation and coordination" model (EE efficiency model in Figure 1), but they are gradually extending into the interactions of subjects and mechanisms, as well as to transaction and innovative platforms. However, the report [26] considers these methods in the second turn, most likely because the DT realized basing on connectivity will remain of top priority for a long time.

\subsection{Reports of the United Nations} in 2014 and 2016 on e-government development

UN reports [27, 28] supplement the report [26] with an analysis of the public sector development. Their findings coincide with the conclusions of the report [26], but at the same time they improve some requirements for EE. Particularly, the following needs are emphasized:

$\diamond$ To use in EE not only informational, but also process connectivity of public sector organizations among themselves, with enterprises of other types, and with individuals, which increases the variability and complexity of enterprise management and requirements for security;

$\diamond$ To ensure in EE requirements the "e-participation" of citizens in order to achieve not personal objectives, but those common for the city, the region and the country.
The following should be noted:

$\checkmark$ Engineering of the informational and process connectivity of organizations and systems has been included in EE for a long time. During the past two decades EE concepts have been recorded in the interoperability standards [31], but the problems with operability of methods of these concepts implementation require conducting further R\&D;

$\checkmark$ The reports [27] and [28] highlight the problems and risks of a non-technological nature in the engineering of ecosystems with active users, and this requires research and inclusion of risk management concepts for both these risks and those that are not yet known in EE.

\section{Evaluation of the classical EE paradigm operability and the nature of its development}

\subsection{Operability of the classical EE paradigm}

Two main DT areas highlighted above are development of classic production operations and new types of information and communication results acquisition. Evaluations of sufficiently full operability of the classical EE paradigm concepts for the first mentioned area have also been formulated. It should be noted that this conclusion also spreads to such a powerful trend as Industry 4.0, where enterprise engineering is being performed with a very high level of automation and connectivity to provide a really large and obvious increase in efficiency, but, in fact, it is still carried out in the scope of classical concepts.

Earlier, a conclusion was also reached about the applicability of the EE classical paradigm for the second, relatively newer area of the DT. However, its relative novelty requires a more detailed approach to evaluation of this area and application to it of the classical EE concepts. In particular, comparative evaluation of the transformations volume within the two mentioned areas, as well as costs estimation for the modernization of the existing business processes and IT systems required for implementation of innovative solutions are useful. Precise estimates of the global volumes of work in these areas are not available, but the volume of modernization of basic production processes for the classical products and services is understood to be many times greater than the volume of purely innovative works. To support this evaluation, let us refer to the Gartner estimate for the next years prospects [32], claiming that by 2019 every dollar invested in innovations will require an additional seven dollars for the modernization of the 
core of the existing business processes and production systems.

In the longer perspective, the proportion will be changing, but traditional market capacities are conservative, and the emergence of any new species and even types of products will also require further modernization of the main processes and production systems, that is, continuation of the transformations carried out within the frame of the classical EE paradigm. Apart from that, interactions between the "traditional" and "new" enterprises (their divisions), reflected by the integration model in Figure 1 will remain. It should be noted that these interactions work within a single enterprise or between partner-enterprises (the similar conclusion is drawn in the report [26]). This means that EE paradigm should include those concepts that apply not only to the "digital leaders", but also to enterprises or parts of enterprises of various types and "digitization" levels, as well as to interactions of such different-type enterprises and their divisions.

Therefore, the global nature of the DT tasks and the level of real production operations development make it possible to forecast that in the perspective under consideration the classical EE paradigm will be operable in the vast majority of engineering cases for both areas of transformation.

\subsection{Openness and the nature of paradigm development}

Operability of the classical EE paradigm also relies on the possibility to apply in EE new concepts in parallel or even in conjunction with the classical ones, as well as to apply alternative concepts. As examples of the concepts defined already in the first decade of the 21st century, the following can be highlighted:

$\diamond$ Use (as opposed to elimination) of manifestations of general-cultural and professional multiculturalism for work enrichment (which was formulated in the paper [3]);

$\diamond$ Involvement of customers in active co-creation within an enterprise ecosystem (which was formulated and methodically provided in the papers $[27,33]$ ), as opposed to offering them only unified products (possibly with tailoring for consumer needs).

Requirements for the EE to carry out all the works with the help of strictly engineering-and-analytical methods ("technocratic concept") and the requirements to transform in the first place the human relations and philosophy of work, starting with the behavior patterns of managers ("humanitarian concept") can be mentioned as an example of the classical alternative EE concepts. Problems in practical joint application of these concepts are great enough, which requires creating additional methods for their harmonious combination, however, both of them are parts of the classical paradigm, enriching it.

There are other problems in the practice of EE application as well (in particular, a problem of the integrated ontology concept implementation and related with it an interoperability problem), a more detailed analysis of which is going to be considered in a separate publication. It is important to note that so far the problems associated with disadvantages of methods and tools for implementing concepts or lack of an adequate concept have been settled (when they could be settled) on account of the openness of EE discipline as a system. This fact has been expressed in EE's continuous expansion through new methods, tools and even concepts, which has not been restricted with the basic standards [1, 2].

Considering all aforementioned, the following answers to the first questions posed in the Introduction can be suggested:

Concepts of the classical EE remain fully operable for the majority of enterprises interacting with each other;

$\downarrow$ Within the limits of the horizon under consideration, the "picture of EE world" is undergoing expansion, but no radical change can be observed; therefore, there are no grounds to talk about the need for a new EE paradigm or a radical paradigm shift of the existing paradigm.

It is supposed that with the forecasted development of technologies and enterprises on the horizon under consideration, new operable EE concepts can continue to be used in conjunction with classical ones, as well as with their expansions. This also applies to such significantly new concepts as, for example, engineering of non-classical forms of management under high uncertainty conditions or engineering of multi-agent systems with different types of actors incorporating robots into the enterprise as its subjects. Thus, it is possible to talk about the quite specific nature of EE development, namely, about the continuously expanding EE paradigm, and a sketch of its development is shown in Table 1. In this Table, already operating new concepts that were formulated at the beginning of the 21 st century are named "Operating and relatively new concepts", and the result of inclusion of these concepts in EE is named "Extended classical EE paradigm". 
Table 1.

Expanding enterprise engineering paradigm: sketch of development

\begin{tabular}{l|c|c|c|c} 
& \multicolumn{4}{c}{ Period (roughly) } \\
\cline { 2 - 5 } & $1992-2000$ & $1995-2000$ & 2001-2010 & 2011-2016-2030 \\
\hline \multirow{2}{*}{ Set of proposed EE conceptions } & Basic EE concepts & Additional EE concepts & $\begin{array}{l}\text { Operating and relatively } \\
\text { new EE concepts }\end{array}$ & $\begin{array}{c}\text { Essentially new concepts } \\
\text { including prospective ones }\end{array}$ \\
\hline Initial state of EE paradigm & Classical EE paradigm & & \\
\hline Current operating state of EE paradigm & & $\begin{array}{c}\text { Extended classical } \\
\text { EE paradigm }\end{array}$ & \\
\hline $\begin{array}{l}\text { General behavior of EE paradigm } \\
\text { development }\end{array}$ & \multicolumn{3}{c}{ Permanently expanding EE paradigm } \\
\hline
\end{tabular}

It should be noted that many publications using words about a new paradigm or about a radical paradigm shift, which is the same, suggest in reality just variants of EE components. One more framework variant for EE [4], one more method of matching the business and IT [8], or any method or variant of tool language can be given as examples. These new EE components can claim to be expanding EE practice, but not to be changing the "picture of EE world"? The paper [34] with more thorough conclusions speaks about the necessity of a big and hard work for a new EE paradigm forming to respond to "great challenges". Besides, the paper forecasts that exploring and solving new problems can be expected by 2025. However, analysis provided in our article demonstrates that many "great challenges" mentioned in [34] might be responded to without any paradigm shift; although changing the meaning of an "enterprise" as a concept might actually require changing " $\mathrm{EE}$ world picture" in the future.

\section{Conclusion}

The period from 1992 and presumably to 2030 is characterized by the emergence of a set of new factors strongly influencing enterprises, as well as by conscious efforts to take these factors in EE into consideration. Such factors include new technological opportunities accompanied by new risks, a sharp increase in volatility and uncertainty of the enterprise environment, as well as a number of other factors. However, the nature of the purposeful creating and functioning of enterprises remains unchanged in general; the concepts of the classi- cal EE paradigm have forestalled most of the mentioned factors, and emerging new concepts can be applied in parallel and often in conjunction with the classical ones, even if they are alternative thereto.

Consequently, within the context of the prospects under consideration, the "picture of the EE world" is undergoing expansions and changes, but no radical paradigm shift is taking place. There exist grounds to believe that throughout the entire horizon under consideration, we are dealing with a continuously expanding EE paradigm able to take into account changes in the environment and to apply new methods and technologies. Contributing factors are both the open nature of the set of concepts in the standards and methodologies of the enterprise engineering and architecture and a high degree of gradation of changes in the inherent character of the enterprises themselves.

At the same time, certain problems are observed when applying EE concepts, and to solve these problems we need further development of those methods and tools realizing them. In addition, relevance of such new engineering concepts that have been recently related to the field of futurology is growing. In this regard, within a separate publication, it is planned to analyze the problems of applying some of the most important EE concepts, both classical and new ones, as well as to highlight areas of further R\&D for some of them.

This analysis will be also associated with defining conditions under which the transition to a truly new EE paradigm would be justified. Announcing the publication of the next portion of EE changes analysis re-

\footnotetext{
${ }^{2}$ In 2013 , the author of this paper gave way to the mainstream pressure and named the system of relevant EE principles proposed in the papers $[6,9]$ as a "new paradigm". Here this name is disavowed for the reasons discussed above. However, the content of the papers [6,9] remains still valid and constructive.
} 
sults, it can be said that these conditions are for now associated in the first place neither with technologies, nor with other new productive forces, but with changes in the productive relations that form the main characteristic features of an enterprise (for example, those related with new values for the consumer and for the enterprise).That is, forming a new EE paradigm might become objectively justified when the meaning of concepts "enterprise" and "EE" themselves changes radically. It is also important to separate the objective and subjective reasons for forming a new EE paradigm.

\section{References}

1. ISO 14258:1998(en). Industrial automation systems - Concepts and rules for enterprise models (with Cor.1:2000, p.6).

2. ISO 15704:2000(en). Industrial automation systems - Requirements for enterprise-reference architectures and methodologies (With Am.1: Additional views for user concerns. 2005, 17 p.).

3. Pedersen P.B. (2001) Multiculturalism and the paradigm shift in counselling: Controversies and alternative futures. Canadian Journal of Counselling, vol. 35, no. 1, pp. 15-25.

4. Dietz J.L.G., Hoogervorst J.A.P., Albani A., Aveiro D., Babkin E., Barjis J., Caetano A., Huysmans P., Iijima J., van Kervel S.J.H., Mulder H., Op‘t Land M., Proper H.A., Sanz J., Terlouw L., Tribolet J., Verelst J., Winter R. (2013) The discipline of enterprise engineering. International Journal of Organisational Design and Engineering, vol. 3, no. 1, pp. 86-114.

5. Telnov Yu.F. (2013) Evolyutsiya paradigmy "inzhiniring predpriyatiy" [Enterprise engineering paradigm evolution]. Proceedings of the XVI Conference "Enterprise Engineering and Knowledge Management”, 25-26 April 2013, Moscow, Russia. Moscow: MESI, pp. 294-298 (in Russian).

6. Guzik S.V., Zinder E.Z., Yunatova I.G. (2013) Novaya paradigma inzhiniringa predpriyatiya i upravlenie sootvetstviem mezhdu rabochimi protsessami i kompetentnost'yu ikh ispolniteley [New enterprise engineering paradigm and compliance management for work processes and their executors' competence]. Proceedings of the XVI Conference "Enterprise Engineering and Knowledge Management", 25-26 April 2013, Moscow, Russia. Moscow: MESI, pp. 90-100 (in Russian).

7. Zinder E.Z. (2012) Novoe v arkhitekturakh predpriyatiy i ikh IT-sistem: vozmozhnosti i riski The novel in the enterprises architectures and their systems: Opportunities and risks]. Proceedings of the 7th International Conference "Modern Enterprise Governance Technologies and Information Systems Usage Opportunities: State, Problems, Perspectives”, 30-31 March 2012, Odessa, Ukraine. Odessa: ONU, pp. 148-152 (in Russian).

8. Hinkelmann K., Karagiannis D., Thoenssen B., Woitsch R., Gerber A., van der Merwe A. (2016) A new paradigm for continuous alignment of business and IT: Combining enterprise architecture modeling and enterprise ontology. Computers in Industry, no. 79, pp. 77-86.

9. Zinder E.Z. (2014) Formirovanie sistemy ponyatiy i printsipov kak bazisa novoy paradigmy inzhiniringa predpriyatiy [Forming new system of concepts as a base of a new paradigm of enterprise engineering]. Proceedings of the XVII Conference "Enterprise Engineering and Knowledge Management”, 24-25 April 2014, Moscow, Russia. Moscow: MESI, pp. 118-126 (in Russian).

10. Stroud D.J. (2002) The impact of the new technologies - Permanent paradigm shift or transitory aberration? Interactive Marketing, vol. 4, no. 2, pp. 144-155.

11. Jackson G., Ahuja V. (2016) Dawn of the digital age and the evolution of the marketing mix. Journal of Direct, Data and Digital Marketing Practice, vol. 17, no. 3, pp. 170-186.

12. Zinder E.Z. (2008) Arkhitektura predpriyativa v kontekste biznes-reinzhiniringa. Chast' 1 [Enterprise architecture in the context of business reengineering. Part 1]. Intelligent Enterprise, no. 4, 10 March 2008, pp. 46-51 (in Russian). Available at: https://www.iemag.ru/master-class/ detail.php?ID=15745 (accessed 29 October 2016).

13. Liles D.H., Johnson M.E. Meade L. (1996) The enterprise engineering discipline. Proceedings of the Fifth Annual Industrial Engineering Research Conference, May 1996, Minneapolis, pp. 479-484.

14. Kosanke K., Nell J.G. (eds.) (1997) Enterprise engineering and integration: Building international consensus. Proceedings of ICEIMT’97 International Conference on Enterprise Integration and Modelling Technology, 28-30 October 1997, Torino, Italy. Springer-Verlag.

15. Bloom H.M. (1997) Enterprise integration - A United States view. Proceedings of ICEIMT'97 International Conference on Enterprise Integration and Modelling Technology, 28-30 October 1997, Torino, Italy. Springer-Verlag, pp. 6-19.

16. Kosanke K., Vemadaf F.B., Zelm M. (2000) Enterprise engineering and integration in the global environment. Advances in Networked Enterprises. N.Y.: Springer, pp. 61-70.

17. IFIP-IFAC Task force on architectures for enterprise integration (1999) GERAM: Generalised enterprise reference architecture and methodology. Version 1.6.3, March 1999.

18. Vernadat F.B. (1998) The CIMOSA languages. Handbook on architectures of information systems. Springer-Verlag, pp. $243-264$.

19. Chen D., Doumeingts G. (1996) The GRAI-GIM reference model, architecture and methodology. Architectures for enterprise integration. Series "IFIP advances in information and communication technology". Springer, pp. 102-126.

20. Martin J. (1995) Evolution of a species. Computerworld, vol. 29, no. 15, p. 37.

21. Martin J. (1996). Cybercorp: The new business revolution. N.Y.: Amacom (American Management Association).

22. Hammer M., Champy J. (1993) Reengineering the corporation: A manifesto for business revolution. N.Y.: Harper Business.

23. Zinder E.Z. (1996) Novoe sistemnoe proektirovanie: informatsionnye tekhnologii $i$ biznes-reinzhiniring. Chast' 3 [New system design: Information technologies and business reengineering. Part 3]. SUBD, no. 2, pp. 61-76 (in Russian).

24. Zinder E.Z. (1996) Proektirovanie baz dannykh: novye trebovaniya, novye podkhody [Database design: New requirements, new approaches]. SUBD, no. 3, pp. 10-22.

25. Timmers P. (1998) Business models for electronic markets. Electronic Markets, vol. 8, no. 2, pp. 3-8.

26. IBRD (2016) Digital dividends. World development report. International Bank for Reconstruction and Development.

27. UN (2014) United Nations e-Government survey 2014. E-Government for the future we want. N.Y.: United Nations. 
28. UN (2016) United Nations e-Government survey 2016. E-Government in support of sustainable development. N.Y.: United Nations.

29. UN (2015) Sustainable Development. Transforming our world: the 2030 Agenda for sustainable development. Available at: https://sustainabledevelopment.un.org/post2015/transformingourworld (accessed 29 October 2016)

30. Evans P.C., Gawer A. (2016) The rise of the platform enterprise (A global survey). The Center for Global Enterprise. The Emerging Platform Economy Series, no. 1 .

31. GOST R 55062-2012 (2012) Informatsinnye tekhnologii. Sistemy promyshlennoy avtomatizatsii i ikh integratsiya. Interoperabel'nost'. Osnovnye polozheniya [Information technologies. Industrial automation systems and integration. Interoperability. Basic principles]. Moscow: Standartinform (in Russian).

32. Plummer D.C., et al. (2016). Top strategic predictions for 2017 and beyond: Surviving the storm winds of digital disruption. Gartner. Available at: https://www.gartner.com/doc/3471568?ref=unauthreader\&srcId=1-6595640685 (accessed 29 October 2016).

33. Zinder E.Z., Yunatova I.G. (2016) Synergy for digital transformation: Person's multiple roles and subject domains integration. Proceedings of the Conference "Digital Transformations \& Global Society" (DTGS 2016), 23-24 June 2016, St. Petersburg, Russia. Springer International Publishing, vol. 674, pp. 155-168.

34. Lapalme J., Gerber A., van der Merwe A., Zachman J., De Vries M., Hinkelmann K. (2016) Exploring the future of enterprise architecture: A Zachman perspective. Computers in Industry, no. 79, pp. 103-113.

\section{Расширяющаяся парадигма инжиниринга предприятия³}

\section{E.3. Зиндер}

Председатель правления, НКО «Фонд поддержки системного проектирования, стандартизации и управления проектами» (Фонд «ФОСТАС»)

Адрес: 107061, г. Москва, а/я 563

E-mail: ezinder@fostas.ru

\section{Аннотация}

Характер изменений парадигмы инжиниринга предприятий (ИП) и, в первую очередь, концепций этой комплексной дисциплины важен для выбора направлений развития ИП, форм накопления знаний в данной сфере и их передачи специалистам, а также устойчивости и гибкости применения ИП на практике. Анализ этих изменений особенно важен по причине высокой турбулентности методов и технологий ИП на современном отрезке развития технологий, производственных и других отношений, а также из-за возможности трактовки частных схем и методов ИП как новой парадигмы.

Для обоснованной оценки изменений парадигмы ИП определены базовые и дополнительные концепции ИП, составившие в конце XX века классическую парадигму ИП. Изложены результаты сравнительного анализа концепций классической парадигмы ИП и задач, общих для разных предприятий до 2030 года. При этом показано, что классическая парадигма ИП сохраняет работоспособность в этой перспективе. Указывается на открытый характер совокупности концепций и методов парадигмы ИП, благодаря чему в ее состав естественным образом включаются концепции, сформулированные уже в XXI веке, а также альтернативные концепции. При этом общая «картина мира ИП» не меняется на несовместимую с прежней, но и не остается неизменной: происходит постоянное расширение парадигмы ИП за счет новых методов реализации концепций, а также новых концепций, применяемых параллельно и совместно с классическими.

Проведенный анализ позволил перейти к определению новых по существу и вновь появляющихся концепций, к предложению направлений дальнейших исследований, а также к определению условий, при которых формирование и применение действительно новой парадигмы ИП может быть оправданным.

Ключевые слова: предприятие, инжиниринг предприятия, концепция инжиниринга, информационная технология, цифровая трансформация, классическая парадигма, сдвиг парадигмы, расширяющаяся парадигма.

Цитирование: Zinder E.Z. Expanding enterprise engineering paradigm // Business Informatics. 2016. No. 4 (38). P. 7-18. DOI: $10.17323 / 1998-0663.2016 .4 .7 .18$.

\footnotetext{
${ }_{3}^{3}$ Работа выполнена в рамках проекта РФФИ 16-07-01062 «Разработка методов и средств инжиниринга предприятий на основе интеллектуальных технологий»
} 


\section{Литература}

1. ISO 14258:1998(en). Industrial automation systems - Concepts and rules for enterprise models (with Cor.1:2000, p.6).

2. ISO 15704:2000(en). Industrial automation systems - Requirements for enterprise-reference architectures and methodologies (With Am.1: Additional views for user concerns. 2005, 17 p.).

3. Pedersen P.B. Multiculturalism and the paradigm shift in counselling: Controversies and alternative futures // Canadian Journal of Counselling. 2001. Vol. 35. No. 1. P. 15-25.

4. The discipline of enterprise engineering / J.L.G. Dietz [et al.] // International Journal of Organisational Design and Engineering. 2013. Vol. 3. No. 1. P. 86-114.

5. Тельнов Ю.Ф. Эволюция парадигмы «инжиниринг предприятия» // Сборник научных трудов XVI конференции «Инжиниринг предприятия и управление знаниями» (ИП\&УЗ - 2013), 25-26 апреля 2013 г., г. Москва. М.: МЭСИ, 2013. С. 294-298.

6. Гузик С.В., Зиндер Е.З., Юнатова И.Г. Новая парадигма инжиниринга предприятия и управление соответствием между рабочими процессами и компетентностью их исполнителей // Сборник научных трудов XVI конференции «Инжиниринг предприятия и управление знаниями» (ИП\&УЗ - 2013), 25-26 апреля 2013 г., г. Москва. М.: МЭСИ, 2013. С. 90-100.

7. Зиндер Е.3. Новое в архитектуре предприятий и их ИТ-систем: возможности и риски // Сборник трудов 7-й Международной конференции «Современные технологии управления предприятием и возможности использования информационных систем: состояние, проблемы, перспективы», 30-31 марта 2012 г., г. Одесса, Украина. Одесса: ОНУ, 2012. С. 148-152.

8. A new paradigm for continuous alignment of business and IT: Combining enterprise architecture modeling and enterprise ontology / K. Hinkelmann [et al.] // Computers in Industry. 2016. No. 79. P. 77-86.

9. Зиндер Е.3. Формирование системы понятий и принципов как база новой парадигмы инжиниринга предприятий // Сборник научных трудов XVII конференции «Инжиниринг предприятия и управление знаниями» (ИП\&УЗ - 2014), $24-25$ апреля 2014 г., г. Москва. М.: МЭСИ, 2014. С. 118-126.

10. Stroud D.J. The impact of the new technologies - Permanent paradigm shift or transitory aberration? // Interactive Marketing. 2002 . vol. 4. No. 2. P. $144-155$.

11. Jackson G., Ahuja V. Dawn of the digital age and the evolution of the marketing mix // Journal of Direct, Data and Digital Marketing Practice. 2016. Vol. 17. No. 3. P. 170-186.

12. Зиндер Е.З. Архитектура предприятия в контексте бизнес-реинжиниринга. Часть $1 / /$ Intelligent Enterprise. 2008 . № 4 (10 марта 2008 г.). С. 46-51. [Электронный ресурc]: https://www.iemag.ru/master-class/detail.php?ID=15745 (дата обращения 29.10.2016).

13. Liles D.H., Johnson M.E. Meade L. The enterprise engineering discipline // Proceedings of the Fifth Annual Industrial Engineering Research Conference, May 1996, Minneapolis. P. 479-484.

14. Kosanke K., Nell J.G. (eds.) Enterprise engineering and integration: Building international consensus // Proceedings of ICEIMT'97 International Conference on Enterprise Integration and Modelling Technology, 28-30 October 1997, Torino, Italy. Springer-Verlag, 1997.

15. Bloom H.M. Enterprise integration - A United States view // Proceedings of ICEIMT'97 International Conference on Enterprise Integration and Modelling Technology, 28-30 October 1997, Torino, Italy. Springer-Verlag, 1997. P. 6-19.

16. Kosanke K., Vemadaf F.B., Zelm M. Enterprise engineering and integration in the global environment // Advances in Networked Enterprises. N.Y.: Springer, 2000. P. 61-70.

17. IFIP-IFAC Task force on architectures for enterprise integration. GERAM: Generalised enterprise reference architecture and methodology. Version 1.6.3, March 1999.

18. Vernadat F.B. The CIMOSA languages. Handbook on architectures of information systems. Springer-Verlag, 1998. P. $243-264$.

19. Chen D., Doumeingts G. The GRAI-GIM reference model, architecture and methodology. Architectures for enterprise integration. Series "IFIP advances in information and communication technology". Springer, 1996. P. 102-126.

20. Martin J. Evolution of a species // Computerworld. 1995. Vol. 29. No. 15. P. 37.

21. Martin J. Cybercorp: The new business revolution. N.Y.: Amacom (American Management Association), 1996.

22. Hammer M., Champy J. Reengineering the corporation: A manifesto for business revolution. N.Y.: Harper Business, 1993.

23. Зиндер Е.З. Новое системное проектирование: информационные технологии и бизнес-реинжиниринг. Часть 3 // СУБД. 1996. № 2. C. 61-76.

24. Зиндер Е.3. Проектирование баз данных: новые требования, новые подходы // СУБД. 1996. № 3. С. 10-22.

25. Timmers P. Business models for electronic markets // Electronic Markets. 1998. Vol. 8. No. 2. P. 3-8.

26. Digital dividends. World development report. International Bank for Reconstruction and Development, 2016.

27. United Nations e-Government survey 2014. E-Government for the future we want. N.Y.: United Nations, 2014.

28. United Nations e-Government survey 2016. E-Government in support of sustainable development. N.Y.: United Nations, 2016.

29. Sustainable Development. Transforming our world: the 2030 Agenda for sustainable development. United Nations, 2015 [Электронный pecypc]: https://sustainabledevelopment.un.org/post2015/transformingourworld (дата обращения 29.10.2016).

30. Evans P.C., Gawer A. The rise of the platform enterprise (A global survey) // The Center for Global Enterprise. The Emerging Platform Economy Series. 2016. No. 1

31. ГОСТ Р 55062-2012. Информационные технологии. Системы промышленной автоматизации и их интеграция. Интероперабельность. Основные положения. М.: Стандартинформ, 2012

32. Top strategic predictions for 2017 and beyond: Surviving the storm winds of digital disruption / D.C. Plummer [et al.]. Gartner, 2016. [Электронный ресурc]: https://www.gartner.com/doc/3471568?ref=unauthreader\&srcId=1-6595640685 (дата обращения 29.10.2016).

33. Zinder E.Z., Yunatova I.G. Synergy for digital transformation: Person's multiple roles and subject domains integration // Proceedings of the Conference "Digital Transformations \& Global Society" (DTGS 2016), 23-24 June 2016, St. Petersburg, Russia. Springer International Publishing. 2016. Vol. 674. P. 155-168.

34. Exploring the future of enterprise architecture: A Zachman perspective / J. Lapalme [et al.] // Computers in Industry. 2016. No. 70. P. $103-113$ 